\section{RAK THI TONG \\ MONTRA: A MODERN \\ INTERPRETATION OF \\ PHRA LO IN THE \\ RATTANAKOSIN \\ PERIOD $^{1}$}

\section{Cholada Ruengruglikit ${ }^{2}$}

\begin{abstract}
Rak Thi Tong Montra [Magic Love] is written in the form of novel by Thommayanti. The story line of this novel is still the same as that of Lilit Phra Lo, a well-known traditional Thai literature in the Early Ayutthaya Period. Though the plot is kept, many changes are made to suggest the writer's new themes and purpose. Thommayanti tells the story by using the younger princess to narrate the story in the form of a memoir. Due to Thommayanti's purpose, some changes in characterization are made and some events are inserted.
\end{abstract}

${ }^{1}$ Revised from the paper of the same title presented in the $7^{\text {th }}$ International Conference on Thai Studies at Amsterdam, The Netherlands, July 4-8, 1999.

${ }^{2}$ Ph.D.,Associate Professor, Department of Thai, Faculty of Arts, Chulalongkorn University, Bangkok, Thailand.
While the idea of karma is stressed in Lilit Phra Lo, the vengeance of Somdet $Y a$ is focussed instead in this novel. Thus the love story is changed into revenge though the tragic end of the hero and heroines is well kept. In this novel a lot of poetry from Lilit Phra Lo are quoted to express the writer's deep appreciation of the classical literature. It is a good example of the influence of Thai classical literature on the creation of modern literary work.

\section{Introduction}

Lilit Phra $\mathrm{Lo}^{3}$ is a well-known Thai classical literature composed in the Early Ayutthaya Period. There are many reproductive works of Lilit Phra Lo in the Rattanakosin Period which shows how well-known Lilit Phra Lo is and how much Thai people appreciate it. Rak Thi Tong Montra is one of these reproductive works.

This paper aims at studying the presentation of a traditional literature, Lilit Phra Lo, in Rak Thi Tong Montra which is written in a popular form of contemporary work, a novel, with the writer's modern interpretation. The influences and continuation of the traditional Thai literature on this work will be examined. 
This paper ${ }^{3}$ is divided into 6 parts:

1. Rak Thi Tong Montra: its background

2. Rak Thi Tong Montra: a rendition Phra Lo in the Rattanakosin Period

3. Rak Thi Tong Montra: the latest novel version of Phra Lo

4. Rak Thi Tong Montra: a new version of Phra Lo

5. Rak Thi Tong Montra: a modern interpretation

6. Rak Thi Tong Montra: the influences of poetry from Lilit Phra Lo

${ }^{3}$ Lilit Phra Lo is one of the well-known Thai classical literature which, is according to most Thai scholars nowadays, was composed in the Early Ayutthaya Period. Some scholars indicate that its story comes from Along Chao Samlo or Opiam Samlo or Upiam Samlo. However, I do not agree with them because the story is very different. Along Chao Samlo is the love story of Samlo and Nang Opiam. Samlo is a travelling trader, who comes to Opiam's city to meet with her. Before getting back home, he promises to marry her. Later on Opiam is pregnant so she leaves for his city. When she arrives, Samlo is trading in another city and Opiam is chased away by his mother though she is about to give birth. Opiam delivers on her way back home and her child dies. She is seriously ill when she arrives home and finally dies too. As soon as Samlo knows about Opiam, he sets out to look for his wife. When he finds that she has been dead, he commits suicide. After their deaths, Samlo and Opiam become stars shining side by side in the sky.

\section{Rak Thi Tong Montra: Its Background}

Thommayant $i$ is a pseudonym of Wimon Siriphaibun, a well known Thai novelist. She wrote Rak Thi Tong Montra in a form of a novel of thirty seven chapters presented to the readers chapter by chapter in a forthnightly magazine, Khwanruean, in the year 1966 and 1967.In the year 1968 all the story of this novel from the beginning to the end was first published by Bamrungsan Publishing in a binding of a pocket book. This novel is quite well known. The latest, the sixth edition, is printed after the year 1994. [The year of this latest edition is not indicated.]

Rak Thi Tong Montra : A Rendition of Phra Lo in the Rattanakosin Period

Rak Thi Tong Montra is not the first Thai literary work which is reproduced from Lilit Phra Lo. There were already twelve literary works before Rak Thi Tong Montra. All of them were written in the Rattanakosin Period since the reign of King Rama I to the present time. These twelve works are one didactic Khlong, five dramatic plays or Bot Lakhon and Bot Lakhon Phut, one Lilit which is a 
genre of poetry composed of Rai and Khlong, two tales written in the form of Klon or Khamklon, and the other three works in the form of a novel.

The only one didactic Khlong is Phra Lo Son Lok composed by an unknown poet in the reign of King Rama I.

The five dramatic plays four of which are Bot Lakhon Ram and the other is Bot Lakhon Phut are as follows:

\section{Bot Lakhon Rueang Phra Lo}

Noralak composed by

Kromphraratchawangbowon

Mahasakdi ponsep in the reign of

King Rama III

2. Bot Lakhon Rueang Phra Lo composed by Chao Phraya Thewetwongwiwat and Luang Monyothanuyok in the reign of King Rama V

3. Bot Lakhon Rueang Phra Lo composed by Nai Chin in the reign of King Rama V

4. Bot Lakhon Rueang Phra Lo composed by Phrachaoboromawongthoe Kromphranarathippraphanphong in the reign of King Rama V

5. Magic Lotus composed by Prem Chaya in the reign of King Rama VIII
The only one Lilit is Lilit Phra Lue written by Luang Simahosot in the reign of King Rama IV.

The two versions written in Klon are Phra Lo Kham Klon by Captain Luang Thuai Han Raksa and Phra Lo Lert Lop by an unknown poet in the reign of King Rama V

The three novels before Rak Thi Tong Montra are Phuean Phang by Yakhop in the reign of King Rama VII, Rak Thi Thuk Moen [an unrequited love], a thirty-chapter novel,composed by Nittaya Nattayasunthon in the year 1955 in the reign of King Rama IX and Phra Lo Chabap Roi Kaeo by Sa-nguan Chotsukharat in the year 1960 in the present reign. As mentioned before, $R a k$ Thi Tong Montra is written during the years 1966 and 1967 and after Rak Thi Tong Montra, there are still many versions of Phra Lo in the reign of the present king such as Bot Lakhon Rueang Phra Lo by Suthiwong Phongphaibun, Pra Law The Magic Lotus by Suraphon Wirunrak, Lodilokrat by Phatthrawadi Sitrairat and Phra Lo Roi Kaeo by Non Narakon etc. So Rak Thi Tong Montra is one rendition of Phra Lo or Phra Lo tale among the various versions in the Rattanakosin Period. 
Rak Thi Tong Montra : The Latest Novel Version of Phra Lo

Rak Thi Tong Montra written between the years 1966-1967 by Thommayanti is the latest novel version of Phra Lo. The other versions are Phra Lo, Phuean Phang by Yakhop in the year 1933, Rak Thi Thuk Moen by Nittaya Nattayasunthon in the year 1955, Phra Lo Chabap Roi Kaeo by Sa-nguan Chotsukharat in the year 1960.

The main story of Rak Thi Tong Montra and its details, come from the wellknown traditional Thai literature, Lilit Phra Lo. And though Thommayanti has not stated what was the inspiration of her work, the use of point of view and the attitude of the writer shows that it is influenced by Rak Thi Thuk Moen, a novel which was written in the year 1955 by Nittaya Nattayasunthon who asks for sympathy for Phra Lo's wife, Laksanawadi.

Nittaya Nattayasunthon tells the story through the hero's wife, Laksanawadi. Thus, the viewpoint is different from Lilit Phra Lo which uses omniscient point of view. While Laksanawadi is telling the story, she can inspire sympathy for herself. So the readers easily feel sorry for her in losing her husband, Phra Lo, due to the intrigue of the two princesses who bring destruction to Phra Lo and Laksanawadi.

Thommayanti's choice of point of view and attitude towards the heroines of the story is undoubtedly influenced by Nittaya Nattayasunthon, the author of Rak Thi Thuk Moen. The narrators of these two novels are character-narrators, Laksanawadi in Rak Thi Thuk Moen and Phangthong in Rak Thi Tong Montra.It seems that Thommayanti wants to make excuses for the two princesses who are the objects of accusations by Nittaya Nattayasunthon. This idea can be seen in the introduction of this novel as quoted in the following example.

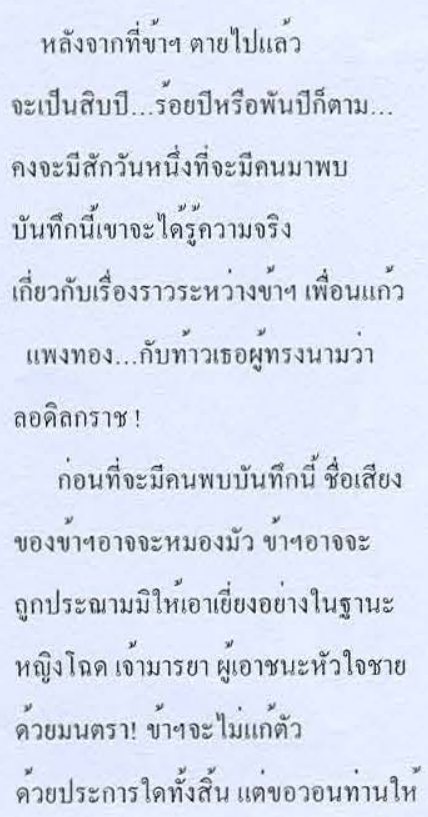


อานบันทึกนี้จนจบ คราวนี้ทานอาจจะ

อภัยใหข้าฯได้วักน้อยนิดก็ยังดี...

บางทีท่านอาจจะให้ความเห็นใจข้าฯ

ได้อาง...(หน้า 5 )

After my death, may be ten years, one hundred or one thousand years later on, there will be some day that someone will find this memoir.

He will then know the truth of our story, Phueankaeo

Phangthong and the king,

Lodilokrat.

Before this memoir is found, our reputation may be tainted. We will be condemned as cunning women who win a man's love by magic incantation. We will not make any excuse, but will beg you to read this memoir. And you may forgive us, even only a little bit and sympathize with us.

Thommayanti expresses her sympathy for the two princesses, Phueankaeo and Phangthong. Thommayanti gives the role of the narrator to Phangthong, the younger princess who is one of the main characters in the story. She narrates the story by writing a memoir, beginning with the scene in which she, her elder sister and their lover are going to die by Somdet $Y a$ 's orders. After that she goes back and tells about the past in order to link all events altogether. The novel begins:

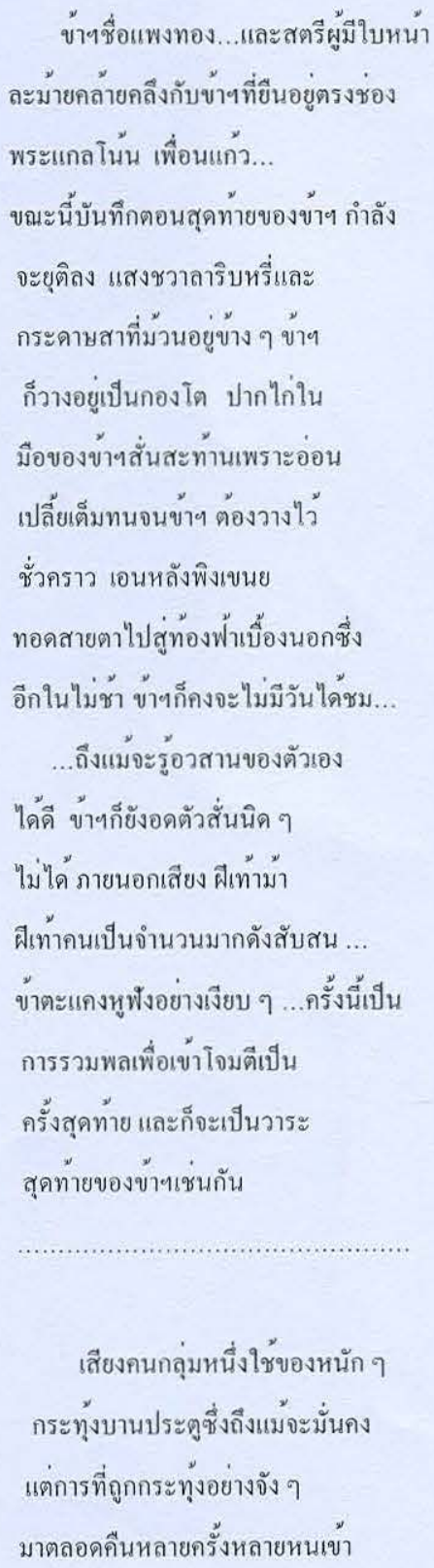




$$
\begin{aligned}
& \text { ท้ายสุดก็เริ่มหวั่นไหว...ประตูบาน } \\
& \text { ใหญ่เริ่มมีรอยแยก ... ผู้ที่ยืนชิดข้าฯ } \\
& \text { จนได้ไออุ่นนี้คือลอดิลกราช และ } \\
& \text { เบื้องขวาโน้นก็คือผู้รวมสายโลหิต } \\
& \text { ของข้างเอง...รอยแยกนั้นกว้างพอแล้ว! } \\
& \text { เสียงโหอึงคนึงฟังไม่ได้ัพท์ } \\
& \text { แสงไต้สว่างจับตา! ข้าฯ เพื่อนแก้ว } \\
& \text { แพงทอง...ขอลา! (หน้า 6) }
\end{aligned}
$$

My name is Phangthong and the lady at the window whose face is a reflection of mine is Phueankaeo.

Now I am writing the last part of my memoir. The lamp light is almost extinguished. Many rolls of $\mathrm{Sa}$ paper lay near me. The pen in my hand is trembling because I am too tired and have to place it down for a while. I recline on a pillow, looking at the sky outside. Soon I will not have time to see it again ... Though I know well my end, I can not help shaking a little bit. There is a confusing sound of men and horses outside... I silently strain to hear the sounds. They are going to attack for the last time.

It will be my last day too.

I hear the breaking of the door by a group of soldiers. Though this door is sturdy, it is finally shaking after a lot of hitting. ... The big door begins to crack.

The man who stands so close that I can feel the warmth is Lodilokrat and the woman who is on the right is my own twin sister. The crack at the door is wide enough.

The shouting of the soldiers is loud and confusing. The torch light is very bright. We, Phueankaeo and Phangthong have to bid farewell.

Thommayanti's original idea of having Phangthong write a memoir in order to narrate the story is different from most Thai traditional literary works which are told by the poet, the omniscient narrator who does not feel sympathy to any character. As a narrator, Phangthong can well explain her ideas, feelings and reasons of her deeds and thus can well ask for sympathy from the readers since she herself takes part in the story.

\section{Rak Thi Tong Montra: A New Version of Phra Lo}

As Phangthong narrates the story, many details are changed, compared to Lilit 
Phra Lo. These are the outstanding characteristics of this new version.

First,Thommayanti changes the names of Phra Lo, Phra Phuean and Phra Phang in Lilit Phra Lo to Lodilokrat, Phueankaeo and Phangthong who are twin, not sisters as indicated in Lilit Phra Lo.

Second, the opening scene in this novel is different from Lilit Phra Lo. This novel begins with the last day of Phangthong's life, when she is finishing her memoir which tells about her life, her sister's and Phra Lo's. The tragedy in this scene is the result of Somdet Ya's resentment. But Lilit Phra lo begins with the war between King Mansuang and King Phimphisakhon which causes Somdet Ya's resentment because King Phimphisakhon, her husband, is killed in this war. During the attack of the enemy and the burning of the weapons hall, Somdet Ya encourages Phueankaeo and Phangthong, her two grandchildren, to swear to get revenge of their grandfather's death, or they hope to die by weapon or by fire. And from time to time, she reminds the princesses not to forget their words.

Third, King Mansuang is shot by King
Phimpisakhon's son, Phichaiphisanukon, before drawing back his troops to his country although this event does not exist in Lilit Phra Lo.

Fourth, in this novel, the resentment of Somdet $Y a$ is strongly stressed and is very important to the development of the story though Thommayanti still keeps the theme of love story of the hero and heroines in Lilit Phra Lo.

Fifth, Thommayanti increases the role of some characters in Lilit Phra Lo; Somdet Ya, Phra Nang Darawadi, the princesses' mother, $P u$ Chao Saming Phrai and even Phra Lo. For example, Somdet Ya plays important roles before the war begins. Her sadness at the gathering of all people in the royal court before her husband goes to defend his country is emphasized. Phra Nang Darawadi takes care of her city, commanding the soldiers to resist the invasion of the enemies while the king and his son, her husband, are fighting against King Mansuang outside the city. Pu Chao Saming Phrai is the guardian god of Mueang Song and he helps Somdet $\mathrm{Ya}$ to avenge her dead husband by giving her a magic wax to anoint the two singers' lips so that their singing will capture the hearts of the listeners. 


\section{Rak Thi Tong Montra}

The using of this magic wax is added to this novel to make it convincing because Phra Lo's infatuation with the princesses after hearing the song praising their beauty is quite nonsense to the readers nowadays. Moreover, Phra Lo's victory over King of Phayao is added. The new King of Phayao is an ally of Somdet Ya in her plot to kill Phra Lo etc.

Sixth, the two princesses can see what happenned to Phra Lo in his country in the witch's and Pu Chao Saming Phrai's magic bowl. Thus they can see Phra Lo and fall in love with him. Some incidents seen in the magic bowl are:

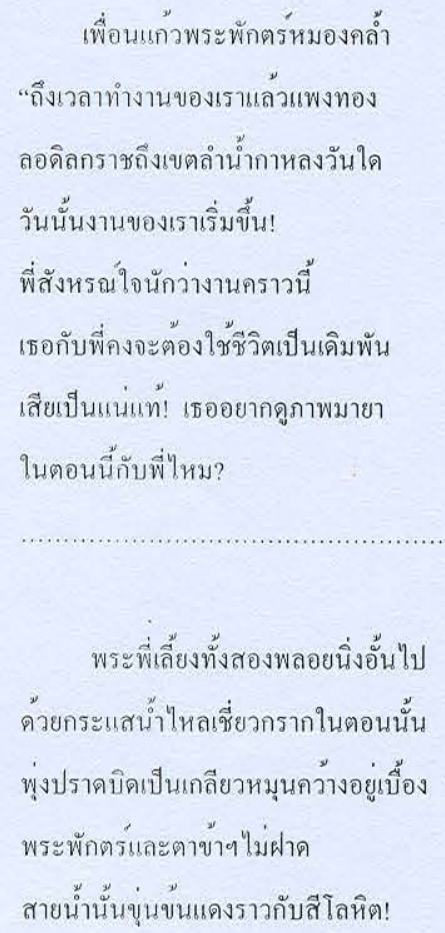

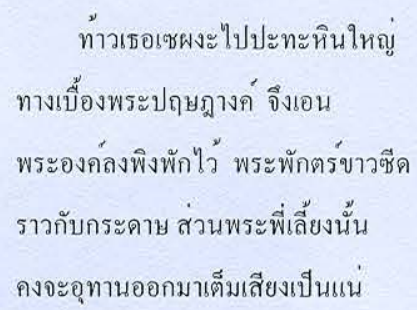

The two attendants are also speechless. The torrential stream swirls before their eyes My eyes are not mistaken. That stream is as red as blood!

He staggers backwards and stumbles against big stone behind his back and rests on it. 
His face is as white as paper. His two attendants exclaim in fright.

[Quotation from Lilit Phra Lo: Upon his words, the stream whirls in a frenzy, red as if coloured with blood, before his eyes. His mind is full of suffering as if a hundred trees fall on his chest.]

Phueankaeo immediately stretches out her hand to touch the holy water bowl, so the vision disappears.

This give the princesses a chance to know what is happenning to Phra Lo and how to help him from the terrible plan of Somdet Ya.

However, Thommayanti still keeps a lot of details from Lilit Phra Lo especially the important ones. For example, a $P u$ Chao Saming Phrai's student who volunteers to guide the princesses'two attendants to go to the residence of $P u$ Chao Saming Phrai; the name of the two elephants, Plai Thiam Lom and Phayu, on which the princesses' two attendants ride to meet $P u$ Chao Saming Phrai; the hero's name, Siket, while he disguises himself as a brahman; the spell that $P u$
Chao Saming Phrai uses to lure Lodilokrat to the princesses'city; the statement of Lodilokrat's attendants to advise their king to be patient with the inconveniences of staying in a rural area of the princesses' country and so on. The following examples are quoted to support the above discussion.

Thommayanti inserts the princesses' order that their two attendants ride Plai Thiamlom and Phra Phayu to the residence of Pu Chao Saming Phrai in her novel.

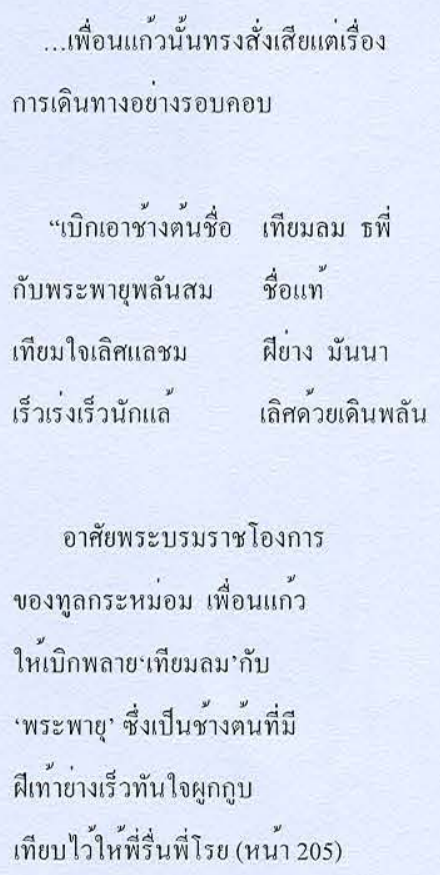

Phueankaeo plans

carefully for this journey. 
[Quotation from Lilit Phra Lo:

Please ask for the royal elephant, Thiamlom and Phra

Phayu which are as fast as their names.]

By the king's order,

Phueankaeo has Plai

Thiamlom and Phra

Phayu, the fastest royal

elephants, tied with

a seat on their back to

prepare for Phi Ruen

Phi Roi's journey.

Thommayanti also inserts Phra Lo's two attendants'words to remind Phra Lo to be patient and try to feel happy during the difficult journey through the forest.

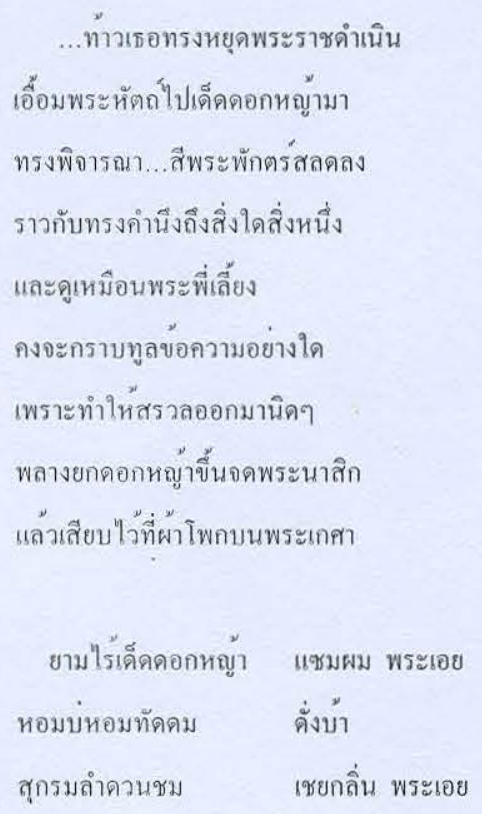

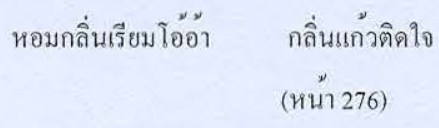

He [Phra Lo] stops walking to, pick a wild flower, which he contemplates for a while. His face turns sadden as if it reminds him of something. It seems that his attendants say something to him which makes him laugh a little while lifting the wild flower to his nose and then puts it on his turban. [Quotation from Lilit Phra Lo:

In time of hardship, pick up a wild flower to decorate your turban.

Though without sweet smell, place it behind an ear and smell it like mad. Admire Sukrom and Lamduan flowers during the hard time.

Oh! how sweet

Kaeo flowers smell! ]

In addition, sometimes though Thommayanti does not quote the poetic writing from Lilit Phra Lo, she keeps the meaning and expresses in her own words. This can be seen in the narration when Pu Chao Saming Phrai visits the 
two princesses. In Lilit Phra Lo, the description of the poet is as follows:

\author{
ตามองเสือบพรับ เห็นเสือ \\ กลับเป็นแมวแถวจราศศุภลักษณ์ \\ มลักเห็นโฉมปู่เจ้า แปรรูปเฒ่า \\ หงอกสกาว คิ้วขาวขนตาเผือก \\ กลับตระเหลือกเป็นบาว ...(หน้า 366 ) \\ When looking at the \\ tiger, it turns to be many \\ cats lining up very \\ beautifully. They see \\ $P u C h a o$, who is an old \\ man with white hair, \\ eyebrows, and \\ eyelashes, turn into \\ a young man.
}

The paraphrasing of the above description in the novel is as follows:

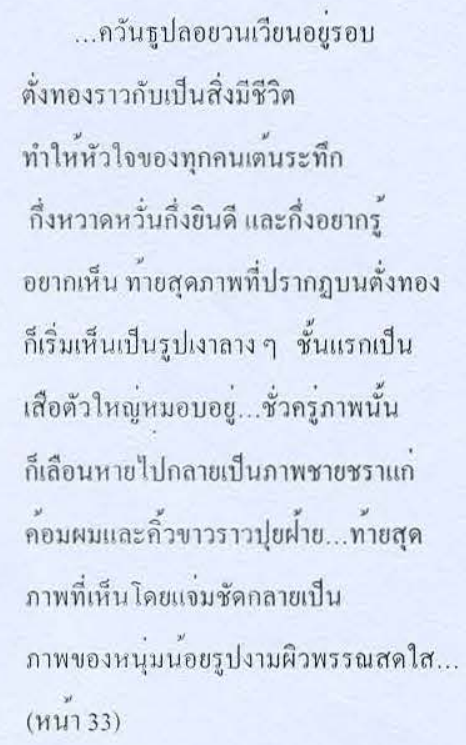

...The joss stick smoke is floating around in the air as if it were alive. This makes everyone's heart excited, half frightened, half pleased, and very curious. Finally, they see a vague from on the golden bed. First, the form appears to be a big crouching tiger. After a while, the tiger turns into a humpbacked old man whose hair and eyebrows are as white as cotton....At last, it changes into a vivid picture of a bright-complexioned young man...

\section{Rak Thi Tong Montra : A Modern Interpretation}

Thommayanti's modern interpretation of Lilit Phra Lo is seen in Rak Thi Tong Montra's theme and characterization.

The tragic love of Phra lo, Phra Phuean, and Phra Phang in Lilit Phra Lo is due to their own karma. Like other Thai literature, the karma of a character sets the direction of his destiny. The idea of karma is strongly stressed in Lilit 
Phra Lo as can be seen in $\mathrm{Pu}$ Chao Saming Phrai's words when he agrees to help lure Phra Lo to the princesses; he says that the hero and heroines have to meet because of their karma. In addition, it can also be seen in Phra Lo's words when he tells his mother that his karma forces him to leave his city to the princesses'. Somdet $Y a$ 's vengeance at the end of Lilit Phra Lo is not considered the cause of the hero and the heroines'death. On the contrary, the idea of Karma is given less importance in the novel. Instead, Somdet Ya's resentment is stressed and it is the key factor to the development of the story. The love of the hero and heroines is planned by Somdet $\mathrm{Ya}$ as part of the plot to take the hero's life. Somdet Ya's words during the war shows vividly her resentment.

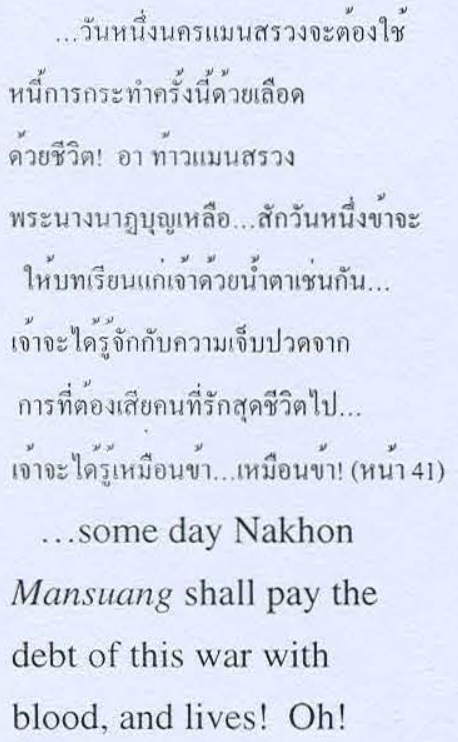

King Mansuang, Phra

Nang BunLuea...

some day I will make you

know with tears this

lesson as well...You

will know the pain of

losing someone dearest to you

You will know as I do

....as I do!

She also tries to cultivate the resentment in her grandchildren's mind, to remind them not to forget that Mueang Mansuang is the important enemy of their country. This can be seen in Somdet $Y a$ 's words to her grandchildren after her husband has led his troop to war outside the city and later on it can be seen again when the weapons hall is burnt down by the enemy. In addition, she forces the two princesses to swear to take revenge for her. If they break their vow, they will die by fire or by weapons.

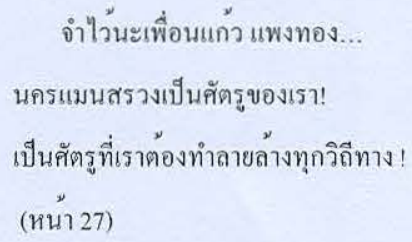

Remember, Phueankaeo Phangthong ...Nakhon Mansuang is our enemy... the enemy we have to destroy in every way. 


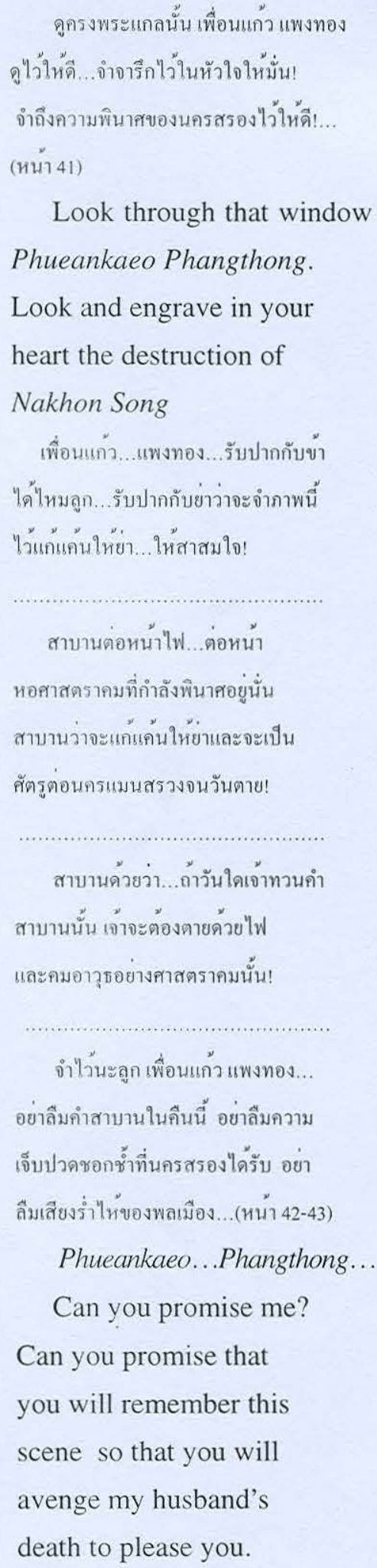

Look through that window Phueankaeo Phangthong. Look and engrave in your heart the destruction of Nakhon Song

Phueankaeo...Phangthong...

Can you promise me? Can you promise that you will remember this scene so that you will avenge my husband's death to please you.

Swear before the fire, before that weapons hall which is burning down. Swear that you will get revenge for me, and be the enemy of Nakhon Mansuang until your dying day.

Swear as well whenever you break your vow, may you die by fire or by weapon as those in the weapons hall.

Remember, Phueankaeo Phangthong, don't forget your vow this night. Don't forget the embittered pain of Nakhon Song. Don't forget the crying of the people.

Thus it can be said that the princesses' death is also caused by their vow breaking. Phangthong also suggests that the result of breaking a vow affects them. when she is attacked by Somdet Ya's soldiers.

The strong emphasis on Somdet Ya's resentment makes it very convincing 
why Somdet Ya orders the soldiers to kill Phra Lo. In Lilit Phra Lo, Somdet Ya's resentment is vaguely presented though it is quite reasonable that the war causes the resentment. Thommayanti explains this point very clearly.

Somdet $Y a$ 's resentment begins when her husband has to leave her to fight against the invaders. It becomes stronger when her husband is killed. It reaches the peak when Phra Lo's victory over King of Phayao is glorified. Her resentment is strongly stressed throughout the story. While the karma of the hero and the heroines is focussed in Lilit Phra Lo, the karma of the hero and heroines and the fruit of misdeeds of their ancestors, King Phimphisakhon's death caused by King Mansuang, though mentioned in the novel, are not emphasized.

In our modern time, most people do not believe in karma, a traditional belief which was very important in the past. So Thommayanti decreases the role of karma in her novel and gives more emphasis on the idea of resentment instead. The idea of resentment and vengeance are generally seen and easily understood by the people nowadays. The victims of revenge are heard and seen in the newspapers or in a lot of incidents in our society. Thus the resentment and vengeance of Somdet $Y a$ is the cause of the tragic love and destiny of the hero and heroines in Rak Thi Tong Montra. Somdet Ya's resentment is beyond any reason. She wants to kill Lodilokrat to give in return a pain of losing a beloved son to his mother. During the war between Thao Chueng and Lodilokrat, she wants Lodilokrat to be defeated without realizing that her desire is very dangerous to her own country. Besides, she lures Lodilokrat to be killed in her country without any thought of her two grandchildren's reputation in unshamefully luring Lodilokrat, a married man to be their lover At last, not only Lodilokrat but also her two grandchildren are her vengeful victims. Actually, her life is also the victim of her resentment and revenge because she, King Phichaiphisanukhon's step mother, is severely punished to death by the king, the princesses' father.

Thus it can be concluded that the grandmother's resentment and vengeance which are not much focussed in Lilit Phra Lo is a strong motivation in this novel and replaces the idea of karma in importance. 
Due to the grandmother's desire to get revenge, $P u$ Chao Saming Phrai uses incantations to lure Lodilokrat to leave his city to meet the princesses.

In addition, it is not only the resentment of the grandmother but also that of the princesses and that of the princesses'father too which cause the death of other people. The grandmother's resentment causes the hero's and the heroines'death. The resentment of the king afterwards cause the death of the grandmother and of the soldiers who help the grandmother to kill Lodilokrat, the two princesses and their four attendants.

As for characterization, Somdet $Y a$ in this novel is very clever. As soon as she hears the song praising her grandchildren's beauty created by the princesses' attendants, she gets the idea of using this song to lure Phra Lo, her enemy's son, into her hands. She plans very carefully, step by step. She asks $P u$ Chao Saming Phrai to make wax to anoint the singers'lips so that the song they sing will make Phra Lo crazy about the princesses. Later on she asks $P u$ Chao Saming Phrai to use his magic power to make Phra Lo unable to resist the desire to meet the princesses. She also knows well the encounter of the princesses and her enemy in the garden and later on in her grandchildren's palace because they all are in her eyes. Finally she can kill Phra Lo as she wishes.Thommayanti carefully shows that the two princesses in her novel are different in characters. The elder, Phueankaeo, is like a man. She likes to study governing and fighting. Besides, she dislikes poetry and stringing flowers. In contrast, the younger, Phangthong, can do well all woman's works and is very fond of literature. This is different from the original story in Lilit Phra Lo in which the two princesses always have the same words and behaviours which are very unrealistic for readers in the modern time. Besides, as Phangthong is the narrator of this novel, Thommayanti inserts a lot of poetry that contributes to her narration which is very consistent with her character. It is appropriate justification fo rthe use of poetry in this novel.

Moreover, the use of Phangthong as narrator is not only consistent with her character but also gives the readers a feeling of knowing someone's real life or experience. Because Phangthong, herself, participates in the events or knows well all incidents happening in 
her country and in Lodilokrat's country. Thommayanti uses the alms bowl of $P u$ Chao Saming Phrai and the water bowl of the witch as magic instruments for Phangthong to see all events happening to the hero in his country and on his way to the princesses' city. This technique allows the author to give readers important details continuously through the narration of Phangthong. Moreover, Phangthong, has a chance to express her and her sister's ideas, feelings, and motivation. As a result, the two princesses are obviously sympathetically portrayed. In addition, the princesses send their followers to find out where Phra Lo is on his way to their country,so they can know well about him. Besides, seeing the vision of Phra Lo in the bowl, the princesses especially Phangthong fall madly in love with him. This point is very important because it is quite nonsense for people nowadays to fall in love with anyone one has never seen. This is also Thommayanti's modern interpretation. The readers know how Phangthong feels in the conversation between Phueankaeo and Phangthong when the former asks the latter why she is so worried about Phra lo. Phangthong says it is a pity that Phra Lo whose face is so beautiful will die young. Evenmore, the princesses's feeling of shame to love a married man, is quite a modern idea. In our modern society fidelity and polygamy are unacceptable. In the past, most kings can have many wives, so can Phra Lo, as a great mighty king. The princesses can be his wives if their father allow them.

\section{Rak Thi Tong Montra : The Influences of Poetry from Lilit Phra Lo}

In this novel, the writer inserts a lot of poetry from Lilit Phra Lo which suggests that she has studied the text in details. Pieces of Khlong, Rai and Klon from Lilit Phra Lo are intregrated in the novel from the beginning to the end. A self-appraisal, the evaluation of the work by the poet himself is quoted as if it were Phangthong's self-appraisal after she finishes her memoir. Quotations from Lilit Phra Lo especially appear in the important scenes such as the descriptions of Phra Lo's beauty, the two princesses'beauty, the battles, of Phra Lo's vow at the Kalong River, all people's grief over the deaths of the hero and the two princesses and so on. [Examples of quotation from Lilit Phra Lo that appear in Rak Thi Tong Montra: A self-appraisal of the poet who writes Lilit Phra Lo] 


$\begin{array}{ll}\text { เปนศรีแก่ากผู้ } & \text { ผจงฉันท์ } \\ \text { คือคูมาลาสรร } & \text { เรียบร้อย } \\ \text { เป็นถนิมประดับกรรณ } & \text { ทุกเมื่อ } \\ \text { กลกระแจะต้องน้อย } & \text { หนึ่งได้แรงใจ } \\ & \text { (หน้า 6) }\end{array}$

It is propitious for the poet who carefully composed this work which is as beautiful as a well-strung garland, an ear decoration and perfumed powder, a dash of which is so inspiring.

[Poetry of Khlong praising the beauty of Phra Lo.]

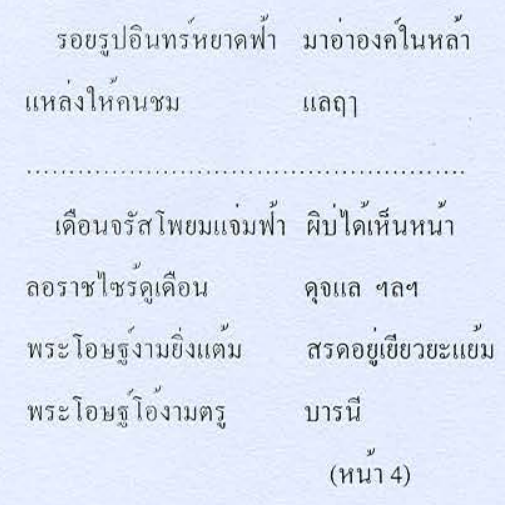

\begin{tabular}{|c|c|}
\hline ขับซอยอราชเที้ยร & ทุกเมือง \\
\hline ฤาเล่าพระลอเลือง & ทั่วหล้า \\
\hline โฉมบาบพิตรเปลือง & ใจโลก \\
\hline สาวหนุ่มฟังเป็นบ้า & $\begin{array}{l}\text { อยู่เพี้ยงโหยหน } \\
\text { (หน้า 130) }\end{array}$ \\
\hline
\end{tabular}

Maybe Indra comes

from heaven in full

manifestation of his beauty to win people's admiration on earth.

If one has never seen his face, just look at the bright full moon. It is as lovely as his face.

His lips'more beautiful than a drawn picture, always seem smiling.

How exceptionally beautiful those lips are!

The singing of the song praising Phra Lo's beauty is heard in every city and widely spreads throughout the world. His beauty captures people's hearts.

All maidens, hearing the song, yearn like mad for him.

\section{[Poetry of Khlong praising the beauty of the two princessses.]}

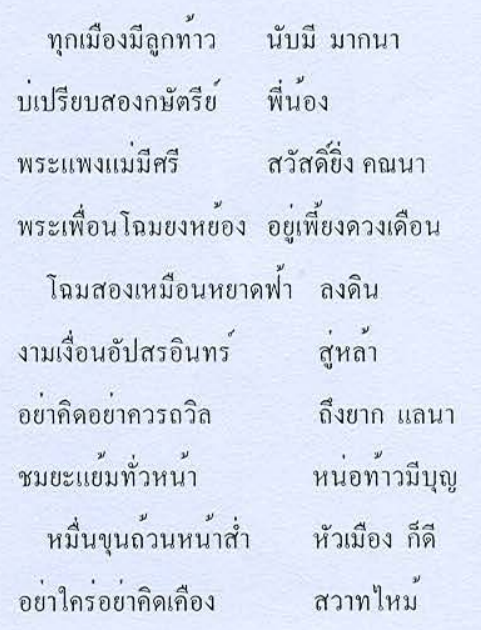




$$
\begin{array}{ll}
\text { สมภารส่งสองเรือง } & \text { สองรุ่ง มานา } \\
\text { สองราชควรท้าวไท้ } & \text { ธิราชผูมีบุญ } \\
& \text { (หน้า 133) }
\end{array}
$$

Among beautiful princesses

in all titles, none is as

beautiful as the two

sister princesses.

Phra Phang is the

most beautiful and

Phra Phuean is as bright

as a full moon. These

two princesses are like

Apsara descending from

heaven to the human world.

No one should bemoan

because it is impossible to

have them as his beloved.

So just look at them

and admire them who

are the king's daughters.

All government officers

in all cities, should not

fancy them and suffer in vain.

Their unsurpassing beauty is

the result of their good

deeds in the past.

They are meant only

for the great mighty king.

Poetry of Khlong describing battles.
หน้าไม้ดาปืนดาษ ธนูสาด
ศรแผลง แข็งต่อแข็งงางาง ...
(หน้า 47)

A loud shouting for victory of the soldiers is heard.A resounding of firearms shakes the land. Soldiers with crossbows and guns in hands are advancing. Arrows are shooting out. Strong soldiers fight against each other.

Poetry of Khlong describing the grief

\begin{tabular}{|c|c|}
\hline สบกษัตริยพระญาติไห้ & อึงอุด อยู่นา \\
\hline สบส่ำสาวสนมทรุด & ท่าวไห้ \\
\hline ปวงนางกำนัลสุด & ถึงไพร่ เมืองนา \\
\hline คนหนึ่งฤาอดได้ & $\begin{array}{l}\text { เกลือกกลิ้งกลางดิน } \\
\text { (หน้ 197) }\end{array}$ \\
\hline เสียงไห้ทุกราษฎร์ไห้ & ทุกเรือน \\
\hline อกแผ่ดินดูเหมือน & จักขว้ำ \\
\hline บเห็นตะวันเดือน & ดาวมืด มัวนา \\
\hline แลแห่งใดเห็นน้ำ & (หน้า 104) \\
\hline
\end{tabular}
of the people due to the death of the hero and the two princesses.

The king and his cousins are weeping loudly. All concubines drop down and cry. Royal maids and servants bemoan their deaths, 
trashing on the floor.

The people in every house shed their tears.

The city's heart seems to turn upside down.

The sun, the moon, and the stars are not seen.

The water everywhere is the tears that flow.

The appropriate insertion of the poetical works from Lilit Phra Lo contributes to the development of the story. For example, when Phueankaeo asks the witch in a Hindu temple, Thewalai, to use her magic power to release Lodilokrat from $P u$ Chao Saming Phrai's incantation, Thommayanti quotes the words of this witch from the same scene in Lilit Phra Lo.

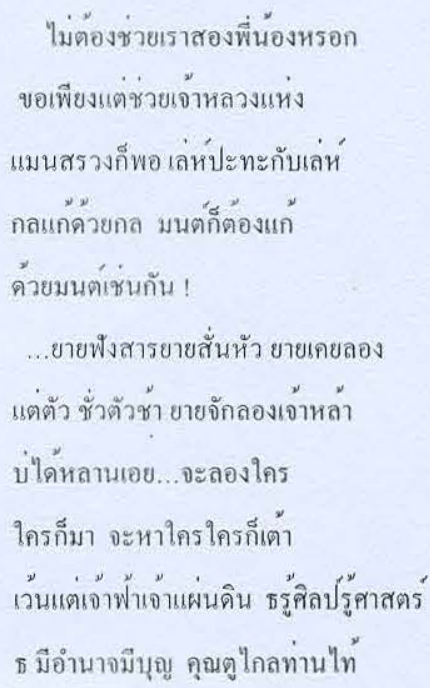

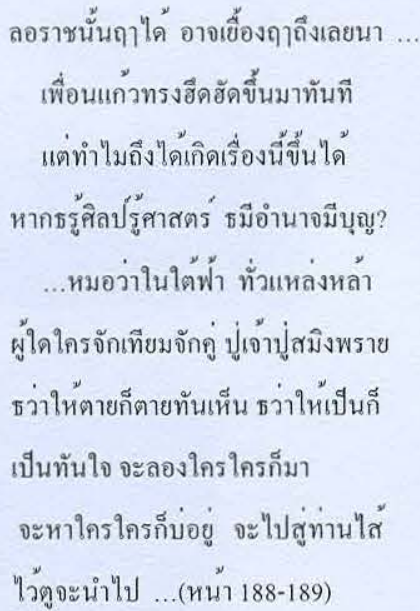

It's unnecessary to help us. Help the king of Mangsuang. Tricks are to be used against tricks, deception against deception, magic against magic.

...After listening to the princesses, Yai, the witch, shakes her head and says that she has tried her magic only on ordinary people. She can't use it with the king. If she orders anyone to come to her, none, except a king, can resist. A king has a lot of knowledge, power and merit. He is beyond my power. So I can't use magic with him.

Phueankaeo says angrily, "Why can this happen, 
if he has a lot of

knowledge and merit?"

The old woman replies that in this world none can compare to $\mathrm{Pu}$ Chao Saming Phrai. He can command anyone's death or put him back to life.

If he wants anyone to come to him, none can resist his order. If you would like to see him, I will lead you to him.

\section{Conclusion}

Rak Thi Tong Montra, a novel originated from Lilit Phra Lo, is presented in the form of a popular modern work, a novel, for the readers of modern time. Thommayanti intends to tell the story from the point of view of Phangthong, to inspire sympathy for Phueankaeo and Phangthong, the heroines of this novel. While the poet of Lilit Phra Lo stresses the idea of karma, Thommayanti gives more importance to vengeance. In order to make her novel convincing for readers in our modern society, a lot of details are added and the change in characterization of important characters and interpretation are made. Somdet $Y a$ 's resentment is strongly stressed as the main cause of all events in the story. Her plan to avenge Phra Lo is presented in details step by step, so the readers can see cleary how she achieves it. This can be considered a new interpretation of Phra Lo. The narration and the characters in this novel are more convincing to readers nowadays than Lilit Phra Lo because modern society and Thai beliefs are very different from those in the past. The idea that karma affects one's destiny is not much accepted by people at present. On the contrary, the resentment and vengeance can be easily understood because they seem to have rationality. Thus Thommayanti changes the love story to a vengeance story, but still keeps the tragic ending of Lilit Phra Lo. This novel is inspired by Rak Thi Thuk Moen as the same kind of narrator, the character-narrator, is used. However, different characters are chosen to tell the story. While Laksanawadi is the narrator in Rak Thi Thuk Moen, Phangthong who of course has a different view narrates is in Rak Thi Tong Montra. Both writers would like to seek sympathy for their narrators who seem to be opponents. Moreover, Thommayanti wants to argue against Nittaya Nattayasunthon's accusation of the two princesses for causing Phra Lo 
and Laksanawadi's tragic destiny. This novel is much influenced by Lilit. A lot of poetical works in the form of Rai and Khlong in Lilit Phra Lo are well inserted in this novel. Some are used to develop the story. This shows how much Thommayanti appreciates Lilit Phra Lo and intends to introduce Lilit Phra Lo to the modern readers in a popular form of the time. This novel is a good example of Thai traditional literature in a modern form with a modern interpretation suitable to the readers'interst and beliefs nowadays.

\section{References}

Suchin Kanphim. 1968. Bot Lakhon Rueng Phra Lonoralak and Bot Lakhon Rueang Phra Lo. Bangkok.

Boonyuen Suwannasi.1989. Phap khong Phra Lo Thi Prakot Nai Bot Lakhon. Sinlapakorn University.

Kromsinlapakorn, 1970. Lilit Phra Lue. Bangkok:

Narathippraphanphong, Krommaphra. 1972. Bot Lakhon Rueang Phra Lo. The 4 edition, Bangkok:
Sinlapabannakhan.

Nittaya Nattayasunthon.1970. Rak Thi

- Thuk Moen. The 2 edition. Bangkok: Bamrungsan Publishing.

Non Narakorn.1990. Pra Lo Roi Kaeo (illustration). Bangkok: Bamrungsan.

Prem Chaya. Magic Lotus.1937. A Romantic Fantasy. Bangkok : Krungthep : Bannakhan Press.

Sa-nguan Chotsukharat.1960 .Phra Lo Chabap Roi Kaeo. Bangkok: Odien Store.

Soison Sakonrak.1997. An Analytical Study of the Transformation of Pra Law Modernization's Literature. Department of Secondary Education, Faculty of Education, Chulalongkorn University.

Maha Sila Wirawong.1943. Thao Hung Rue Chueang.

Thomayanti. 1995.Rak Thi Tong Montra.Bangkok: Na Banwan akam. 


\section{Rak Thi Tong Montra}

Wannakam Samai Ayutthya. 1986. Volume I, Volume II, Bangkok : Kromsinlapakon.
Yakhop.1958. Phuean Phang in Ruam

NiyaiRak. Bangkok: Phadungsueksa. 